\title{
Vitamins and the Risk for Parkinson's Disease
}

\author{
Hassan Ghani; Donald Stevens; Jackie Weiss; and Richard Rosenbaum, MD
}

\section{Background}

Parkinson's disease (PD) is a disease of the nervous system that interferes with brain control of body movement. In PD there is cell damage in an area of the brain that controls movement. This leads to the common symptoms of tremor, balance difficulty, and slowed movements. More information about the symptoms and treatment of PD can be found on the next page.

One theory about the cause of PD blames the brain cell damage on a chemical reaction called oxidation. Certain vitamins, especially carotenoids and vitamins $\mathrm{E}$ and $\mathrm{C}$, may prevent cell damage from oxidation, so they are called antioxidants. The body needs many vitamins in small amounts to maintain health, especially that of the nervous system. The table shows the importance of some of these vitamins.

Because vitamins $C$ and $E$ and carotenoids prevent damage from oxidation, they might reduce the risk of developing PD. In this issue of Neurology, Zhang et al. (Zhang SM, Hernán MA, Chen $\mathrm{H}$,

Spiegelman D, Willett WC, Ascherio $\mathrm{A}$. Intakes of vitamins $\mathrm{E}$ and $\mathrm{C}$, carotenoids, vitamin supplements, and PD risk. Neurology 2002;59: 1161-1169) assessed whether the intake of vitamins $C$ and $E$ and carotenoids either in pills or in foods decreased the risk of developing PD.

This study followed 76,890 women (aged 30 to 55) for 14 years and 47,331 men (aged 40 to 75) for 12 years. All the participants were health care professionals, mainly doctors and nurses. Every 2 to 4 years they filled out detailed surveys about their diets, including their vitamin intake from both foods and pills. A total of 371 people developed PD during the study.

The investigators found that neither vitamin $\mathrm{C}$ nor carotenoid intake lowered the risk of developing PD. The results were the same for the use of vitamin E pills. Surprisingly, participants who ate vitamin E-rich foods as part of their diets developed the fewest cases of PD.

This observation that foods rich in vitamin $\mathrm{E}$ may prevent $\mathrm{PD}$ is preliminary. Future studies will be needed to confirm and explain it. It is possible that it is not the vitamin $E$ but other ingredients in these foods that reduced the risk for developing PD. For example, both nuts and mayonnaise are high in vitamin E. However, while nuts appeared to reduce the risk of PD, mayonnaise did not.

In conclusion, most antioxidants or vitamins are not proven to protect against PD. Whether some foods rich in vitamin $E$ reduce the risk of PD needs further study. Good nutrition is important for all of us and affects many aspects of health besides PD. These preliminary results should not lead you to make drastic changes in your diet.

To find out more about vitamins as part of a healthy diet:

\section{American Dietetic Association www.eatright.org Nutrition Information Line} (800) 366-1655

National Institutes of Health www.cc.nih.gov/ccc/supplements (301) 496-2563

Mayo Clinic Health Oasis www.mayoclinic.com/findinformation/conditioncenters

Table Common vitamins

\begin{tabular}{|c|c|c|}
\hline Vitamin & Function & Food source \\
\hline Vitamin A & $\begin{array}{l}\text { Helps maintain, among other things, skin, bones, immune system, } \\
\text { and vision; excess may be toxic }\end{array}$ & Egg yolks, organ meats, fortified milk \\
\hline $\begin{array}{r}\text { Vitamin B } \\
\text { complex }\end{array}$ & $\begin{array}{l}\text { Helps maintain healthy immune and nervous systems; also } \\
\text { controls blood glucose and metabolism }\end{array}$ & Meat, fish, fortified breakfast cereal, dairy products, banana, potato \\
\hline Carotenoids & Precursors (chemicals that turn into) of vitamin A (antioxidant) & Carrots, sweet potatoes, peaches, and other fruits and vegetables \\
\hline Vitamin $\mathrm{C}$ & Helps to absorb iron and maintain skin tissue (antioxidant) & Oranges and other citrus fruits, strawberries, tomatoes, and broccoli \\
\hline Vitamin D & Helps prevent osteoporosis; excess may be dangerous & Fortified milk, liver, saltwater fish; the body can also make it \\
\hline Vitamin E & $\begin{array}{l}\text { Important to the immune system, helps prevent blockage in } \\
\text { arteries (antioxidant) }\end{array}$ & Vegetable oils, nuts, and whole-grain products \\
\hline Vitamin $\mathrm{K}$ & $\begin{array}{l}\text { Aids in blood clotting; some studies show it may help to maintain } \\
\text { healthy bone structure in the elderly }\end{array}$ & $\begin{array}{l}\text { Cabbage, cauliflower, leafy greens, cereal, soybeans, other } \\
\text { vegetables }\end{array}$ \\
\hline
\end{tabular}




\section{What is Parkinson's Disease?}

Parkinson's disease (PD) is a disease of the nervous system that interferes with the brain's control of body movement. An area of the brain that controls muscle movements deteriorates, decreasing the production of dopamine, a brain chemical also called a neurotransmitter. This makes it difficult for people with PD to control movement. James Parkinson first described this disease in England in 1817.

\section{Causes}

You are more likely to develop PD if you have a father, mother, or sibling with the disease, but for most people with PD, a specific inherited gene is not found.

A few cases of PD can be directly traced to chemical exposures, but a specific environmental cause is not identified in most cases.

Scientists believe a combination of genetic and environmental factors cause the disease. In most cases the cause is unknown.

\section{Signs and Symptoms}

These signs and symptoms are typical of patients with PD. Not all signs or symptoms will appear in every patient.

Tremor-Uncontrolled shaking, particularly in the hands or legs. Tremor is often accompanied by changes in handwriting, difficulty handling small objects, or performing daily activities like buttoning clothes. The shaking may come and go.
Rigidity-Stiffness in muscles, which makes moving difficult. Rigidity is not a loss of strength but rather a loss of control.

Bradykinesia-Slow movement; a loss of ability to move briskly and automatically.

Postural instability-A loss of balance and coordination.

\section{Stages}

Parkinson's disease usually worsens slowly as the years pass. The Hoehn and Yahr scale, which divides PD into five stages, illustrates how the disease can progress.

Stage 1 -The symptoms appear on only one side of the body

Stage 2-The symptoms spread to both sides of the body

Stage 3-Patients begin to lose their sense of balance

Stage 4-Patients need help walking; the other symptoms intensify

Stage 5-Patients require a wheelchair

\section{Treatments}

Currently there is no treatment that prevents the disease or keeps it from progressing. However, there are treatments that can greatly decrease the signs and symptoms:

Levodopa is the most effective drug for treatment of PD. In the United States it is usually combined with carbidopa, which decreases adverse effects, such as nausea and vomiting. Other adverse effects of levodopa, such as abnormal movements called dyskinesias or wearing off drug effectiveness, sometimes develop after a patient has taken the drug for a few years.
Dopamine agonists include bromocriptine (Parlodel), pergolide (Permax), pramipexole (Mirapex), and ropinirole (Requip). These help to correct the message transfer between the brain and body. Adverse effects can include drowsiness, confusion, and hallucinations, but the dopamine agonists are less likely than levodopa to cause some other adverse effects.

Other useful drugs include selegiline (Eldepryl), anticholinergics, and amantadine (Symmetrel).

Surgery, including placement of electrical stimulators in selected parts of the brain, is very helpful for a small portion of patients with PD.

\section{Resources}

The American Academy of Neurology

www.aan.com

\section{American Parkinson Disease}

Association

www.aprdaparkinson.com

National Institute of Neurological Disorders and Stroke

(800)352-9424

www.ninds.nih.gov

Parkinson's Disease Foundation (800)457-6676 www.pdf.org

The National Parkinson Foundation, Inc.

1-800-327-4545

www.parkinson.org 


\title{
Neurology
}

\author{
Vitamins and the Risk for Parkinson's Disease \\ Hassan Ghani, Donald Stevens, Jackie Weiss, et al. \\ Neurology 2002;59;E8-E9 \\ DOI 10.1212/WNL.59.8.E8
}

This information is current as of October 22, 2002

\section{Updated Information \&}

Services

Permissions \& Licensing

Reprints including high resolution figures, can be found at:

http://n.neurology.org/content/59/8/E8.full

Information about reproducing this article in parts (figures,tables) or in its entirety can be found online at:

http://www.neurology.org/about/about_the_journal\#permissions

Information about ordering reprints can be found online:

http://n.neurology.org/subscribers/advertise

Neurology ${ }^{\circledR}$ is the official journal of the American Academy of Neurology. Published continuously since 1951, it is now a weekly with 48 issues per year. Copyright. All rights reserved. Print ISSN: 0028-3878. Online ISSN: 1526-632X.

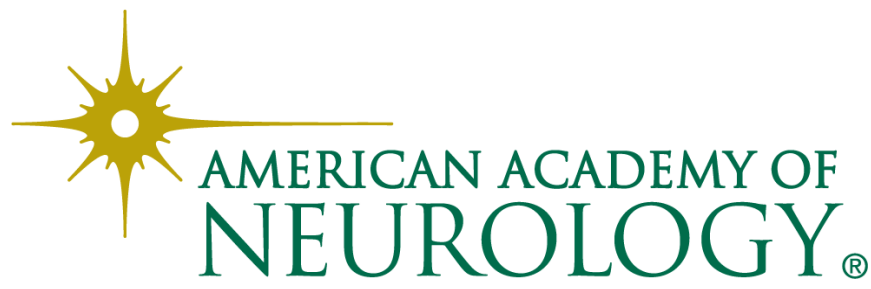

